\title{
"I am not suffering any more..."': Tragic Potential in the Nineteenth-Century Consumptive Myth
}

\section{Meredith Conti}

It was impossible to realize that it was death that was approaching. The child felt no pain - only a tranquil, soft weakness, daily and almost insensibly increasing; and she was so beautiful, so loving, so trustful, so happy, that one could not resist the soothing influence of that air of innocence and peace which seemed to breathe around her.

\section{St. Clare in Uncle Tom's Cabin (1852) ${ }^{2}$}

[T] he Bacillus tuberculosis of Koch must be admitted as perhaps the most powerful member of that dangerous class of microzymes which, in the form of spores, rods, and dots, more than decimate the "lords of the world."

Hugo Engel, "The Etiology of Tuberculosis” (1882)

The paradoxical construction of consumption within overlapping social, literary, and medical spheres (particularly as manifested in the nineteenth century) has been the subject of numerous works in contemporary scholarship, most notably in Susan Sontag's seminal text Illness as Metaphor (1977). As Sontag and other theorists and historians have convincingly argued, consumption was a seemingly kaleidoscopic phenomenon, a unique and shifting blend of fact and fiction within the collective cultural imaginations of several Western populaces (France, England, and the United States chief among them). ${ }^{4}$ The writings of poets, novelists, social commentators, and even physicians of the eighteenth and nineteenth centuries demonstrate that consumption was at once constructed as the disease of passionate lovers, the rich, the young, the white, the brilliant and poetic, the penitent sinner, and the chaste and innocent. Consumption's conceptualized (and yet inseparable) bond with human sensibility and the self, as well as its mythologized capacity for bestowing painless demises upon its victims, made it an exceptionally popular

\footnotetext{
Meredith Conti is a doctoral candidate in Theatre and Performance Studies at the University of Pittsburgh, where she recently was named an Andrew Mellon Pre-Doctoral Fellow. Her essay on the 2006 La Mama revival of Sam Shepard's The Tooth of Crime was published in Journal of American Drama and Theatre (winter 2008). Conti's book reviews have appeared in Theatre Journal, Theatre History Studies, and the New England Theatre Journal. A version of this article was presented at the Literature and Pathology Conference at the University of California, Irvine.
} 
literary device through the late nineteenth century. These same qualities, coupled with the iconic image of the delicate but expressive, pale but flushed consumptive body, made it an equally effective theatrical device in plays like Alexandre Dumas fils' adaptation of his own classic tale of love and consumption, La dame aux camélias (1852).

The employment of consumption in mid-nineteenth century literature (including dramatic works) has frequently been labeled a melodramatic conceit. However, while the cultural construction of consumptive suffering undoubtedly can be read through the contextualizing lens of melodrama, such an appraisal disregards its equally, if not more prevalent, tragic tendencies. This study contends that the nineteenth-century romantic myth of consumption functioned within social, literary, and scientific imaginations as a generic bearer of tragedy. ${ }^{5}$ Indeed, as I will argue, the social standing and intellect of consumption's mythologized victims, the reputed internality of the disease (as opposed to exterior, contagious threats like cholera), the distinctive patient/community relationship, and the dynamics of a consumptive death (including a tragic recognition) ably recommend the consumptive myth as tragic by design. The cultural linking of consumption with the ennobling genre of tragedy served a significant social purpose. In an era in which one English physician boldly calculated that one fourth of the European populace was consumptive, the disease's tragic arch was employed to romanticize the deplorable, to rarify the commonplace, to validate the senseless, and to make legible the illogical. ${ }^{6}$ With Robert Koch's landmark 1882 discovery of tuberculosis's fundamental source, the airborne and contagious tubercle bacillus, the clinical tuberculosis began its prolonged supplanting of the mythologized consumption. Because of its tremendous social and aesthetic currency, the latter construction of tuberculosis resisted its ousting for decades; however, the tubercle bacillus impacted far more than the field of medicine before the most successful treatment for tuberculosis, streptomycin, rendered the disease "cured" among industrialized nations in the 1940s. This essay further asserts that the disease's potency as a carrier of tragic suffering was diminished irrevocably by the slow incorporation of tuberculosis as a contagious and indiscriminate plague of humanity.

In order to position the pre-Koch consumptive myth within the generic realm of tragedy, a number of assumptions must be delineated. First, I agree with Raymond Williams's conviction that a universalist approach to determining the tragic genre neglects the crucial involvement of the historical period in which the work was created and/or interpreted. As Williams asserts in Modern Tragedy: "tragic experience, because of its central importance, commonly attracts the fundamental beliefs and tensions of a period, and tragic theory is interesting mainly in this sense, that through it the shape and set of a particular culture is often deeply realised." Though it is nearly incontrovertible that tragedy's most lingering attributes originate from Aristotelian thought (and indeed, this essay makes use of many of 
them), harvesting all of the genre's characteristics from Poetics presupposes that humankind remains invariable within an ever-evolving world. More specifically, an exclusively Aristotelian evaluation of consumption's tragic potential would necessarily disregard the disease's historically rooted and paradoxical meanings. Therefore, Williams's more fluid understanding of tragedy, one that acknowledges the shifting values and cultural conditions that influence the pre-existing tragic conventions in any given period, informs this study's overarching theoretical framework.

Secondly, as much of the following investigation into the consumptive myth's tragic potential centers on the disease's victims, I would like to avoid defining tragedy as "what happens to the hero" but instead, as Williams advocates, identify "the ordinary tragic action [as] what happens through the hero." Little Eva's consumptive death in George Aiken's stage adaptation of Uncle Tom's Cabin (1852) provides a fitting example: as her health declines, Eva urges her father, St. Clare, to emancipate Uncle Tom. Despite intentions to honor Eva's request and free his slaves, St. Clare's untimely death precludes Tom's legal manumission, setting the play's final causal actions into motion. In analyzing the selfhood of the consumptive sufferer, I hope to elude characterizing tragedy by what the hero endures by gauging the influence of the consumptive self and his/her illness on the surrounding community, using Claudine Herzlich and Janine Pierret's Illness and Self in Society as a model. Lastly, though he defines tragedy far too narrowly for this essay's purposes, Robert B. Heilman's “Tragedy and Melodrama” does provide a useful set of determinants that permit the tragic consumptive myth to morph into non-tragic tuberculosis, a paradigmatic illustration of what Heilman terms a literature of disaster.

After a brief primer on tuberculosis's history and known pathology, this essay will analyze the validity of the consumptive myth's tragic potential using the writings of Aristotle and the genre-theory scholarship of Williams, Heilman, Terry Eagleton, Peter Brooks and Northrop Frye in concert with sociological and historical studies on disease, society, and selfhood. ${ }^{9}$ I will then discuss the gradual reduction of consumption's tragic faculty by examining how the post-Koch construction of tuberculosis constitutes Heilman's non-tragic literature of disaster. To illuminate the tragic actions embedded in the consumptive myth, this essay will employ the support of La dame aux camélias and Uncle Tom's Cabin, both successful stage adaptations of wildly popular novels, as well as Tom Taylor's domestic drama Helping Hands (1855). These plays demonstrate that the consumptive myth operated profitably within the melodramatic form (the overwhelmingly dominant genre of the nineteenth century) without compromising its tragic validity. Succeeding both Koch's discovery and the explosion of Western dramatic realism, George Bernard Shaw's The Doctor's Dilemma (1906), Sean O'Casey's The Plough and the Stars (1926), and Eugene O'Neill's Long Day's Journey Into Night (1940) will aid us in 
recognizing the diminishment of the disease's tragic potential. ${ }^{10}$ My commitment to substantiating this essay's arguments solely with dramatic works, rather than tapping into the wealth of other cultural artifacts advocating the consumptive myth, has a twofold purpose. First, as I am ultimately concerned with the shift in tragic potential of tuberculosis as scientific developments transformed the disease's status within the cultural realm, it is crucial that the investigation finds its way to drama, the incontrovertible locus of the tragic form and its accompanying scholarship. While the consumptive myth boasted an undeniably tragic arch in all of its cultural forms (novels, newspaper editorials, poetry, and even some medical essays), the nineteenth-century stage operated as a laboratory to test the dramatic efficacy, flexibility, and emotional potency of the consumptive myth as a conveyor of tragedy. Second, while recent works by Clark Lawlor, Nan Marie McMurry, B. Meyer, and Athena Vrettos have skillfully chronicled consumption's literary and cultural development through the Romantic and Victorian ages, the disease's regular presence on the nineteenth-century popular stage has garnered far less scholarly attention, save for Linda and Michael Hutcheon's compelling study Opera: Desire, Disease, Death (1996), which considers the "Tubercular Heroines" of La Bohème and La Traviata. With historians estimating that Uncle Tom's Cabin was seen in the theatres by five times more people than it was read, it seems only fitting to expand the discourse's parameters to include tuberculosis's dramatization through adapted and original plays.

Consumption, the wasting disease, phthisis, graveyard cough, the decline, weakness of the lungs: tuberculosis, or more specifically pulmonary tuberculosis, has accumulated an abundance of monikers through over three thousand years of existence. Though tiny tubercles (lesions or nodules) characteristic of the disease can develop in tissues throughout the body, pulmonary tuberculosis was the most prevalent historically and supplied the mythic construction of consumption with most of its emblematic symptoms. ${ }^{11}$ According to Thomas M. Daniel, tuberculosis first reached "astounding epidemic proportions" in Europe in the seventeenth century, with tuberculosis mortality peaking in England in $1780 .{ }^{12}$ The end of the eighteenth century saw a moderate decline of tuberculosis before its widespread resurgence in the nineteenth century. Then, far before any effective treatments were introduced, the rates of those afflicted and dying from tuberculosis ebbed rapidly in the latter half of the nineteenth century. A concrete explanation for this phenomenon has not been widely accepted, but improved nutrition, swifter diagnoses, and even "herd immunity" have all been cited by scientists as possible justifications.

Pulmonary tuberculosis is caused by the airborne bacterium tubercle bacillus that, once inhaled or ingested, may lie dormant or become activated, especially in the immunosuppressed. ${ }^{13}$ Once activated, the bacteria create tubercles that damage 
the vulnerable tissue of the lungs. If left untreated, or if the body's resistance to the disease has been severely compromised, the deterioration of tissue leads to death. "Galloping" or "military" (rapid) consumption was historically less common than chronic, long-term consumption, the latter producing in its early to middle stages "a poor appetite ..., loss of weight, pallor (which often contrasted with an unhealthy flush of the cheeks), night sweats, a chronically running nose and [cough]." ${ }^{14}$ Because tuberculosis incubates for long periods of time, potentially years, and even upon activation divulges few exterior signs of the dormant monster within, early diagnosis was nearly impossible prior to the twentieth century. In the late stages of the disease, however, a diagnosis of tuberculosis is literally inscribed on the sufferer's flushed face and emaciated body. ${ }^{15}$ Wheezing, vocal hoarseness, and shortness of breath are also common consequences of advanced tuberculosis, but it is important to note that, though a consumptive sufferer's voice may fail in her final days, her cerebral faculties remain largely uncorrupted. By no means a linearly progressive disease, tuberculosis was historically associated with periods of remission and relapse that placed its victim on a revolving wheel of hope and despair until death was deemed a certainty. Affirms F. B. Smith, "[consumption] might suddenly advance and kill within weeks, or arrest, or reappear after months or years, or spontaneously go away, independent, seemingly, of the victim's therapeutic regimen." 16 With some mythologizing exceptions, deaths from tuberculosis were and are "extremely unpleasant, with patients becoming more and more short of breath, increasingly unable to control their coughing and expectoration, unable to gain a moment's peace." ${ }^{17}$ As Clark Lawlor remarks in Consumption and Literature: The Making of the Romantic Disease, it seems unfathomable that a disease capable of generating such painful and repulsive suffering could inspire Edgar Allan Poe to profess in his short story "Metzengerstein": "I would wish all I love to perish of that gentle disease. How glorious!"18 And yet the mythic re-construction of consumption, at its full potency in the nineteenth century, bestowed upon the decidedly unglamorous disease the powerful and elegant trappings of tragedy until Koch's discovery pulled back the veil to reveal tuberculosis's "true" identity. ${ }^{19}$

Of the many aspects of the consumptive myth that recommend it as a capable tragic device, the reputation (and situation) of the disease's human carrier operates most profitably within tragedy's classical parameters. For Aristotle, as translated by Kenneth A. Telford, the "most beautiful tragedy" involves not a "wicked" or "villainous" or even "equitable" man changing fortune, but a "sort of man who does not differ in virtue or justice, and who changes to misfortune, not because of badness or wickedness, but because of some mistake, he being a man held in high opinion and of good fortune, e.g. Oedipus, or Thyestes, and notable men of such families." ${ }^{20}$ As conceived of by Arthur Schopenhauer and others, the tragic protagonist's exalted position facilitates "more extravagant plunges from grace" that "render the tragedy more grippingly terrible for the spectators." Moreover, Eagleton 
notes in Sweet Violence: The Idea of the Tragic that "in Hegelian terms, the more prestigious the protagonist, the more immanent the tragedy." ${ }^{21}$ Like the preferred Aristotelian hero, the consumptive myth's victims were rarely faultless, nor were they fundamentally wicked; at times, the disease actually proffered redemption to worthy candidates burdened by past transgressions, as is the case with La dame aux camélias's "soiled dove," Marguerite. In the consumptive myth, the most ideal and fitting sufferers indeed were "held in high opinion and of good fortune," while the nature of the "mistake" that left each hero vulnerable to consumption normally fell into four major categories. Unlike the victims of transmittable (i.e., condemning and unglamorous) diseases like cholera and syphilis, the victims of consumption were rescued from a similarly vulgar fate by the myth's assertion that consumption was inherited through superior ancestry, divinely predetermined, or enticed to manifest itself because of extraordinary genius or passion. ${ }^{22}$

Heredity factored importantly in scientific inquiries into consumption as well as its mythic construction. For multiple relatives to succumb to the disease was an unfortunate but commonplace occurrence in nineteenth-century Europe and North America, as was the case with the famous Brontë family, which lost five of six siblings (and a possible six of seven nuclear family members) to the wasting disease. ${ }^{23}$ However, while the scientific community recognized the majority of consumptive sufferers were society's poor and undernourished, an acknowledgment of these victims would significantly diminish the disease's tragic potential first forged during the Enlightenment, when interconnected eighteenth-century fascinations with the nervous system, emotional delicacy, and aesthetic pulchritude "metaphorically purified [consumption] as the ideal physical disease of sensibility." Indeed, in George Cheyne's Natural Method of Cureing the Diseases of the Body, and the disorders of the mind depending on the body (1742), the society physician theorized that consumption was one of three inter-related plagues of the "young and delicate"" along with "nervous and hysteric diseases." 24 Nervous conditions and hysterical fits, as Cheyne and his contemporaries understood them, indicated not just higher sensibility but also superior social orientation, a crucial characteristic in the building of consumption's tragic potential. The vital, persistent linking of consumption with inherited social superiority and sensibility authenticated and glorified the consumptive body as the ideal symbol of beauty. The voluptuous female figure cherished for centuries as the European model of perfection was starved in the late eighteenth century to replicate the consumptive female's wasting form: sunken chest, long willowy limbs and swan-like neck, "winged" back (labeled thusly because of the severity with which the shoulder blades jutted out of an emaciated torso), translucent skin with flushed cheeks, and fiery, deep-set eyes. The newly minted epitome of female beauty transformed life for fashion-forward European and subsequently American women. Not only was a near skeletal body the new mark of beauty and refinement, but feminine plumpness actually became equated 
with laziness and intellectual slowness. Women underwent relentless tight-lacing of corsets to achieve a diminutive waist, replaced their voluminous, heavy-fabric skirts with pale and airy ensembles resembling the consumptive's thin bedroom shift, "took to drinking lemon juice and vinegar to kill their appetites and make themselves look more alluring," and avoided eating heartily in front of guests, as such behavior was now deemed uncouth and vulgar. Ironically (and perhaps tragically), the extreme techniques employed to transform a healthy body into a consumptive-esque body likely fueled the tuberculosis epidemic. According to Dormandy, "[s] ome doctors claimed that the wearing of such unsuitable attire in winter contributed to the vicious influenza epidemic of $1803 \ldots$ which in turn may have lowered patients' resistance to phthisis." ${ }^{25}$ Though the pristine halls of medicine failed to blockade their scientific studies against the most persuasive components of the myth (with several contemporary medical documents providing elegant, almost appreciative descriptions of the consumptive body), some members of the medical community did attempt to lessen its cultural leverage. The widespread conflation of sickliness with social distinction or delicacy particularly disheartened physician Thomas Beddoes, who urged women to thicken their fashionably frothy garments with a hidden layer of flannel. Lamenting the "indolence" of wealthy ladies who "even in the country, pass many days of the finest season without more exertion than a sauntering walk, or a drive in an easy carriage," Beddoes prescribes a robust regime of diet and exercise for those of wealthy parentage, though his recommendations were rarely heeded. ${ }^{26}$ In imperial Britain's booming global economy, the term "consumption" acquired further meaning as connections were drawn between the disease and material consumption, with contemporary physician Dr. Edward Barry curiously conceiving of consumption as the "inherited" disease of an ever-wealthier, self-indulgent Empire. ${ }^{27}$ As Herzlich and Pierret articulate, the mythologized consumption was the "inherited disease . . . especially liable to befall the rich, the young, women, and the fragile beings consumed by 'the passion of sadness' ... [; ] for them, tuberculosis was also a way of life full of luxury and leisure." ${ }^{28}$

The purported susceptibility of the hereditarily superior (and delicate) to the development of consumption is immediately discernible in Aiken's stage adaptation of Uncle Tom's Cabin. Eva's first spirited entrance into the St. Clare family's "handsome parlor" (act two, scene one) and enthusiastic embrace of her mother, Marie, garners immediate reprobation from the latter: "That will do - take care, child - don't you make my head ache!" Marie scolds as she kisses Eva "languidly," according to the stage directions. As the scene progresses, the St. Clare family's wealth and privilege are foregrounded through discussions of Uncle Tom's purchase and Marie's refined sensibilities and weak constitution. In a manner that would have infuriated Dr. Beddoes, Marie refuses a stroll in the garden with St. Clare and his cousin Ophelia, stating: "I wonder how you can ask such a question, when you know 
how fragile I am. I shall retire to my chamber, and repose till dinner time." Eva's genetic bond to Marie, an archetype of cultivated delicacy, is perfectly in keeping with the consumptive myth's insistence that the disease, just like tragedy, primarily befalls the socially elevated. Eva's consumption is further linked to the tragic flaw of inherited gentility by her aunt Ophelia, who urges St. Clare to coax Eva in from the dewy weather. Eva's "cough," Ophelia attests, is "just the way Eliza Jane was taken - and Ellen." 29 Though the two women are not explicitly identified in the play as relatives, Ophelia's use of first names with her cousin St. Clare suggests Eva's vulnerability to consumption was inherited by virtue of a refined bloodline. ${ }^{30}$

Further strengthening Eva's tragic heroism is her position as a divinely chosen "angel" destined for a short earthly existence. According to Eagleton, the normative sense of tragedy demands that suffering "be largely unmerited, preordained, noncontingently caused . . . , revelatory of divine order, exultantly life-affirming, conducive to dignity and self-knowledge," among other characteristics. ${ }^{31}$ The consumptive myth adopted nearly identical requirements to those of Eagleton's normative tragic mode, depicting consumption as a fated (and mild) method of deliverance for the devout and the innocent. It is Uncle Tom who recognizes Eva as a temporarily earthbound angel whose illness will lead to the fulfillment of her destiny:

Eva: (Pointing to the sky.) I'm going there, to the spirits bright, Tom; I'm going before long.

Tom: It's jest no use tryin' to keep Miss Eva here; I've allays said so. She's got the Lord's mark in her forehead. She wasn't never like a child that's to live-there was always something deep in her eyes. ${ }^{32}$

In Eva's case, heredity and fate conspire together to occasion her tragic fall.

With a formidable predilection for socially superior or divinely chosen consumptive victims, how did the nineteenth-century tragic myth of consumption incorporate the rather renowned "wasting poets" of bourgeois and lower class origins (John Keats and Percy Bysshe Shelley, among others), as well as their similarly classed feminine consumptive muses? For the Romantics, who commandeered the consumptive myth in the late eighteenth and early nineteenth centuries, intellectual or artistic brilliance rendered a person inherently susceptible to consumption, regardless of class. "If a poet," it was thought, "worked too hard and too quickly, his genius at full stretch, mental and physical over-stimulation would eventually result in languorous exhaustion and disease. Mental over-stimulation was especially destructive. ${ }^{933}$ In addition to touching those with genius, the mythologized consumptive was also spurred on by an excessively passionate soul, a derivative 
of the Renaissance linkage of consumption with love melancholy. Herzlich and Pierret note: "Fever and consumption were thus seen as only the physical signs of an inner fire, whether it be of desire or of genius." According to those who employed the consumptive myth, the tragic flaw (or, in Tilford's translation of Aristotle, "mistake") of the consumptive is his or her indulgence of the incendiary impulses within, whether they be materialistic, intellectual, or sentimental: "[ $\mathrm{t}]$ he shining eyes, their 'glowing that matches the pink cheeks,' as [Magic Mountain author] Thomas Mann has put it, came from the fire of a soul that was destroying itself: the consumptives 'burned up their days." "34 Paradoxically, the denial or suppression of inner desires was also thought to invite consumption. "The romantic idea that the disease expresses the character is invariably extended to assert that the character causes the disease - because it has not expressed itself," argues Sontag. "Passion moves inward, striking and blighting the deepest cellular recesses." 35 Both genius and passion elevated a socially inferior consumptive sufferer; in this way, the consumptive myth guaranteed a tragic fall from fortune for the disease's chosen victims, one of whom was La dame aux camélias's Marguerite. ${ }^{36}$

Despite Marguerite's wicked reputation as a courtesan, her delicate beauty, passionate soul, and material trappings of social distinction qualify her for a tragic fall, as furnished by the consumptive myth. Marguerite was famously based on Parisian courtesan Marie Duplessis, with whom Dumas had a passionate affair. Duplessis's profligate lifestyle and delicate consumptive body enchanted Dumas, and her premature death at twenty-three devastated the young writer. In a 1924 piece for the New York Times on the centenary of Duplessis's birth, Lida Rose McCabe describes the courtesan's consumptive beauty: "She was beautiful and elegant. . . Her mouth was small, teeth white and glistening, while her hands and feet were no less fine and adorable than was her body, perfect in grace and distinction. Hers in short was the allure of a duchess." ${ }^{37}$ In this typically romanticized portrayal, Duplessis (and similarly Marguerite) is dissociated from her immoral profession by virtue of her "perfect" consumptive body and awarded the ennobling "distinction" of a "duchess." In addition, though Dumas's dramatization gives no indication of how Marguerite became consumptive, the novel implies heredity, as is noted by Linda and Michael Hutcheon: "[Marguerite's] only legacy from her dead mother is the disease they share." ${ }^{38}$ Marguerite's provincial upbringing leaves her familial social status in question; however, the luxuries "inherited" through her savvy business dealings within a materially consumptive city equip the courtesan with the trappings of social distinction and subsequently a place of superficial "good fortune" from which to tragically descend. Because economic consumption holds hands with physical consumption in the nineteenth century, Marguerite's unrestrained lifestyle is positioned as a character flaw with dire consequences. Sontag posits: "Early capitalism assumes the necessity of regulated spending, saving, accounting, discipline - an economy that depends on the rational limitation of desire. TB is 
described in images that sum up the negative behavior of nineteenth-century homo economicus: consumption; wasting; squandering of vitality. ${ }^{\prime 39}$ As Marguerite succumbs to her physical disease she also sheds her material belongings until, in the play's final act, her austerely outfitted bedchamber matches her depleted corporeal form.

Unlike young Eva's fated demise, what most entitles Marguerite to her tragic end is the burning, passionate spirit she alternately stokes and extinguishes within the course of the play ${ }^{40}$ Both the courtesan's disease and internal fire are present but dormant at the commencement of the play (the latter being inhibited by Marguerite herself in order to circumvent the occupational hazard of falling in love). Théophile Gautier, after viewing the play's first performance on February 2, 1852, at the Théâtre de Vaudeville, noted that at the beginning of the play Marguerite "is not yet transformed by passion ... But then as she begins to be troubled and then filled with real love, she becomes humble, shy, tender - and ill. She is consumed not only by love for Armand but also by the disease which consumes her body. And she knows it. ${ }^{\prime 41}$ Her later suppression of this passionate love at Armand's father's request irrevocably worsens her physical condition. However, Marguerite's abjuration of her feelings only heightens her authority as a worthy tragic heroine.

Marguerite: Within a week, your son will have returned to you, saddened for a while, perhaps, but cured for ever [sic]. Also, I swear to you that he shall never know what has passed between us.

Duval: [kissing Marguerite] You are a noble girl, Marguerite. ${ }^{42}$

Within the strictures of the consumptive myth, Dumas's "noble" Marguerite dooms herself to a tragic demise by the abrupt and total renunciation of her passions.

A riches-to-rags story of love, money, and illness, Tom Taylor's Helping Hands, which premiered at London's Adelphi in June of 1855, endorses the mythologized correlation between the consumptive and artistic genius. At the curtain's rise, the tragic descent of Helping Hands's female consumptive is critically underway. The first scene finds Margaret Hartmann coughing gently and copying music by candlelight in a small, upper-floor room of a poor London boardinghouse, her meager accommodations belying the privileged lifestyle into which she was born. "My earliest recollections are of ease, almost luxury," she discloses to Dr. Merton, her love interest and her father's physician. Herr Hartmann was "first violin at the opera; he had pupils - rich and fashionable ones - he earned much, spent freely, for he thought his position as durable as it was brilliant." Following her mother's consumptive death and her father's gradually degenerating eyesight (ending his 
distinguished career as a musician and instructor), the family "sank, sank, sank, slowly, but surely, from ease to want." ${ }^{\prime 3}$ Margaret's hereditary predilection for consumption is augmented by her deliberate suppression of her passion for music. In order to supplement the paltry tips Hartmann now earns playing his Stradivarius on street corners, Margaret copies music on commission. Having deemed women incapable of musical virtuosity long ago, Hartmann refused to teach his only child how to read and play music. Margaret's musical abilities are self-taught, bespeaking a natural artistic facility; however, the dutiful daughter stifles her proficiency so as not to upset her father, only exercising her gift through her clandestine copying job. Contextualized by the consumptive myth, Margaret's illness seems the inevitable consequence of a perfect storm of genetics, social privilege, and suppressed artistic passion.

In voicing his suspicion that Margaret's persistent cough is symptomatic of consumption, Dr. Merton ventures, "[t]he seeds of that disorder are already implanted in your constitution." 44 While Merton's comment explicitly addresses Margaret's genetic predisposition, his choice of metaphor suggests another crucial affiliation between tragedy and the pre-Koch myth of consumption: the internality of the disease within its victims. Peter Brooks argues in his study of generic interstices between melodrama, tragedy, and comedy that the evildoers of melodrama enter "from down the road. . . . [A] villain, the troubler of innocence, will come to insinuate himself, either under the mask of friendship (or courtship) or simply as intruder." ${ }^{45}$ For the sufferer within the consumptive myth, the enemy is unquestionably (and tragically) internal, annihilating from the inside until there is nothing left to consume. To employ Merton's metaphor, the seeds of consumption organically germinate within and are contained by the consumptive's body. Similar to Brooks, Heilman postulates that tragedy is not exerted on the hero from outside forces, as in melodrama. Instead, Heilman's tragic hero is a divided human fighting an internal battle, grappling with "different incentives and different directions, a pulling apart." Of the three types of divided heroes Heilman details, one strain must choose between "'imperative' and 'impulse,' between the moral ordinance and the unruly passion, between mandate and desire, between law and lust." 46 Dumas's Marguerite best illuminates such an internalized tragic dividedness. Her passionate romance and her lover's pristine bourgeois reputation are mutually exclusive entities, and the courtesan's ultimate choice to safeguard Armand's place within respectable society accelerates her own physical decline. Marguerite's corporeal vessel becomes the archetypal consumptive body as the "tragedy" destroying her from within moves outward.

While the consumptive's personal circumstances and the disease's internality are consistent with several foundational elements of tragedy, the death of the mythologized consumptive further fortifies the association. The relationship between death and tragedy is culturally variable, Raymond Williams argues, 
particularly in the isolation or embracing of the dying by the community. "However men die," he posits, "the experience is not only the physical dissolution and ending; it is also a change in the lives and relationships of others, for we know death as much in the experience of others as in our own experience and endings. ${ }^{, 47}$ Herzlich and Pierret propose a similar interdependence between the ill and society: "Everywhere and in all periods, it is the individual who is sick, but he is sick in the eyes of his society, in relation to it, and in keeping with the modalities fixed by it." In the consumptive myth, before fear of contamination isolated the consumptive from the uninfected community, loved ones frequently nursed ill patients at home and intimately observed their deaths. "In the bourgeois milieus of the early nineteenth century, [consumption] was for the most part experienced in the bosom of the family, enclosed in the intimacy of the bedroom. ${ }^{" 48}$ Charlotte Brontë's letter to a friend upon her sister Emily's death illustrates the faithful care given to a familial consumptive, and the emptiness that materializes with the patient's passing: "her fever is quieted, her restlessness soothed, her deep hollow cough is hushed forever; we do not hear it in the night nor listen for it in the morning; we have not the conflict of the strangely strong spirit and the fragile frame before us." ${ }^{\prime 49}$ In the late 1850 s, the first seaside sanatoria were constructed, offering wealthy consumptives doctor-prescribed "fresh air therapy" in an aesthetically pleasing setting. Though those who occupied these early sanatoria were separated from their families and communities, they were by no means isolated from or condemned by society. In truth, the pre-Koch sanatoria (many resembling luxury resorts rather than medical treatment centers) forged their own inclusive communities of patients and personnel, a multilayered support system for the dying process.

The enveloping of the consumptive by a concerned and benevolent crosssection of society was an especially affective device within the consumptive myth. If the consumptive death was to somewhat retain its gentle reputation (in the face of mounting accounts to the contrary) and operate within the tragic genre, the requisite pain must be partially displaced onto surrogates, the loved ones surrounding the tragic hero. While the young heroes suffer nobly through the prolonged (but ultimately premature) dying process, the community endures the anguish of watching the disease's victims perish. In Uncle Tom's Cabin, St. Clare, Marie, Ophelia, and Uncle Tom encircle the dying Eva, whose tragic suffering transfers to her surrogate, St. Clare. As Eva peacefully slips away, St. Clare cries: "Oh heaven! this is dreadful! Oh! Tom, my boy, it is killing me!" ${ }^{150}$ Likewise, an empathetic and vicariously suffering community comprised of Marguerite's friend Gaston, loyal maid Nanine, and personal physician witness the courtesan's final hours. Of the three consumptives we have discussed, only Helping Hands's Margaret survives through the end of the play; nevertheless, a solicitous congregation intimately observes her illness's progression. Dr. Merton's grave prognosis that "there is danger, great danger, in [Margaret] passing this winter in England" instigates the 
collective relocation of the community (including her father, her now fiancé Merton, the boardinghouse's chambermaid Tilda and her beau, cockney bootblack Rufus) to sunny Naples so that, as Hartmann avows, "her dear cheek [will] grow bright, and her step strong." ${ }^{, 51}$ Despite the uncertainty of Margaret's future health and the logistical improbability of the group's mass exodus from London, it is evident that because of the story's "helping hands," Margaret's tragic end has been successfully averted, if only temporarily.

Perhaps the most direct and convincing evidence that the early nineteenth century consumptive myth was constructed to correspond with the tragic genre is the deliberate inclusion of a recognition, or anagnorisis, directly before the consumptive's death. For Aristotle, "a recognition, as the name signifies, is a change from ignorance to knowledge, and so to either friendship or enmity in those determined to good fortune or misfortune. ${ }^{" 52}$ Frequently prefacing the consumptive's recognition was indeed a state of (hallucinatory) ignorance in which victims failed to recognize their dire situation. B. Meyer offers: "[Consumptives] were believed to suffer a specific unwillingness to recognize the gravity of their situation in that they were held, by both medical and popular opinion, to deny that death was imminent. ${ }^{" 53}$ The consumptive myth regularly employed this phenomenon of spes phthisica, or the "hope of the consumptive," perhaps to substantiate further the disease's relatively painless death. Virginia Poe, Edgar Allan Poe's eighteen-yearold bride, was said to have "attended her last dance the night when she suffered her last and fatal haemorrhage," allegedly under the throes of a delusional restoration of health. ${ }^{54}$ Following the illusory hopefulness of spes phthisica, consumption then bestowed upon its victims a sudden clarity of mind that triggered recognitions, bursting forth in the last stages of the illness. "As the disease progressed," notes Meyer, "sufferers were held to often become more other-worldly ..., more spirited and experiencing heightened intellectual capacities." ${ }^{55}$ Profound and perceptive deathbed speeches, the myth emphasized, were the result of consumptives being "made more conscious as they confront their deaths. ${ }^{.56}$ Such is the case with Little Eva, whose death is punctuated by her magnified spiritual clarity:

St. Clare: Oh Eva! tell us what you see. What is it?

Eva: (Feebly smiling.) Oh! love! joy! peace! (Dies.) ${ }^{57}$

Eva's proclamation falls short of a true anagnorisis, however, as the immediacy of her death precludes any attitudinal or behavioral responses to her sudden insight.

La dame aux camélias's final act benefits structurally and theatrically from Marguerite's "change from ignorance to knowledge" in the form of a full tragic recognition. Under the watchful eyes of her caregivers, the weakened Marguerite is resigned to her imminent death at the act's commencement. With the arrival of 
the besotted and repentant Armand, Marguerite's demeanor abruptly alters:

Armand! I said this morning that only one thing could save me. I had given up hoping for it - and then you came. We must lose no time, beloved. Life was slipping away from me, but you came and it stayed .... Nichette is to be married this morning, to Gustave. Let us go see her married . . . . Bring my outdoor things, Nanine, I want to go out. ${ }^{58}$

The spes phthisica possessing her shatters only when her enfeebled body refuses to cooperate with her rejuvenated optimism. Armand frantically calls for the doctor, to which Marguerite declares: "yes, yes! Tell him that Armand has come back, that I want to live, that I must live." As Nanine exits to fetch the doctor, Marguerite becomes thoughtful. She then verbalizes a stark realization: "But if your coming has not saved me, nothing will. I have lived for love, now I am dying of it." The anagnorisis is swift, simple, and dictates the remaining minutes of Marguerite's life. Lacking any bitterness or anger, she instead ruminates on her possible culpability in her own tragic death: "Perhaps, if things had been different, if I had really been the good girl you should have loved, I might have grieved more at leaving a world where you are, and a future that was so full of promise." ${ }^{59}$ Marguerite's uncomplicated assessment adheres to Northrop Frye's definition of an authentic tragic recognition: "The discovery or anagnorisis which comes at the end of the tragic plot is not simply the knowledge by the hero of what has happened to him . . . but the recognition of the determined shape of the life he has created for himself, with an implicit comparison with the uncreated potential life he has forsaken." ${ }^{\prime 60}$

The performative rituals and theatrical conventions that accompanied nineteenth-century stagings of consumption served to augment its tragic potency. Even more than their source novels, the stage adaptations of Uncle Tom's Cabin and La dame aux camélias emphasize the tragic pathos of Eva's and Marguerite's sickroom vigils by exploiting the popular scenic effect of the tableaux. In an 1881 poster advertising Uncle Tom 's Cabin at Troy, New York's Griswold Opera House, a rendering of the production's "Death of Eva" tableau is prominently featured. Reinforcing the fallacious belief that the consumptive's death is peaceful and painless, a beatific Eva reclines in a high-backed chair, her small body covered in a nightgown and blankets of brilliant white. A heterogeneous collection of friends and loved ones (black and white, male and female, young and old) fills the sickroom, their grief-stricken faces telegraphing their roles as emotional surrogates of Eva's material suffering. ${ }^{61}$ Not surprisingly, the embodiment of diseased characters by actors and actresses provided the tragic consumptive myth with some of its most influential and lingering symbols. The fickle, touch-and-go nature of consumption 
was profoundly theatrical, affording playwrights and actors with a dynamic device capable of producing erratic reversals in health and elongating or truncating the development of symptoms. But given the importance of the elegant and aggrandizing properties of the tragic myth, consumptive performances deemed too realistic or vulgar were often criticized. Playing Camille (as Marguerite Gautier was renamed in Anglo-American productions) at the Harlem Opera House, Adelaide Keim was applauded for "never [acting] hectically ill," but Clara Morris's more naturalistic portrayal of the same character, according to the New York Tribune, "smelled of the drug store and the sick room." ${ }^{\prime 2}$ Perhaps the most recognizable symptom of the disease, the cough, became an integral part of theatricalized consumption's pathology, so much so that reviewers often recorded the frequency and type of coughs utilized by performers playing consumptives. Consumptive coughing and gasping often helped to establish the disease's presence in a character's body more easily than the disease's corporeal markers. Though the physical signs (pale skin, flushed cheeks, hollowed eye sockets, and fragile frame) were important parts of theatricalized consumption, their absence from an actor's performance often had less to do with a deliberate illustration of the disease's early, symptom-free stages than with the actor's own physical health; Margaret Fuller, another American Camille, was regarded by several critics as "too plump to play Camille ideally." ${ }^{63}$

As the preceding analysis has elucidated, the nineteenth-century consumptive myth was interwoven with tragic codes and conventions, but for what purpose? In its theatrical application, the consumptive myth engendered tragic pathos even within melodramatic works. Though it is often equated with representations of other sensationalized afflictions (such as the famed delirium tremens scene in William H. Smith's The Drunkard (1844), for example), consumptive suffering requires an elevated hero whose internal struggles and/or dividedness begets tragic consequences. Eagleton's inventory of the manifold pleasures to be "enjoyed" in the spectacle of tragedy illuminates equivalent values within the consumptive myth:

Tragedy gives pleasure because the purging of excessive emotion is enjoyable in itself; because we take pleasure in mimesis as such, even representations of disasters .... [Tragedy] puts our own petty troubles in chastening perspective. We revel in the steadfastness of the human spirit in the face of mind-wrenching calamity .... [M]oreover, there is pleasure to be had from symbolically rehearsing and so disarming our own deaths, which fictional representations of death allow us to do. ${ }^{64}$

So too did pre-1882 representations of consumption. In broader cultural realms, the consumptive myth appropriated the generic markers of tragedy as a sort of public service. The tragic tropes imbedded within the consumptive myth symbolically 
ennobled the disease's "chosen" victims (both fictional and authentic), legitimated their experiences, and dignified their demises. Most significantly, like Eagleton's conceptualization of the tragic art, which "shapes suffering into a significant pattern, containing it while rendering it agreeably intelligible," the consumptive myth deciphered, consolidated, and made meaningful the diverse experiences of those enduring the disease's bleakest realities. ${ }^{65}$

The consumptive myth maintained its cultural influence through the late nineteenth century, buoyed by the popular expression of its tragic potential in novels, poetry, plays, and newspaper stories. However, in 1882 the myth's Achilles' heel was exposed and wounded, leading to its protracted descent into cultural inefficaciousnous.

The man who shot the arrow was Heinrich Herrmann Robert Koch, a thirtynine year old German bacteriologist and purported "hero of the empire." ${ }^{96}$ While others before him (including stethoscope inventor René Théophile Hyacinthe Laënnec and infectious disease expert Jean-Antoine Villemin) had significantly expanded the disease's known pathology, the notion of "hereditary tuberculosis" resolutely persisted through decades of speculation. ${ }^{67}$ Indeed, published a year before Koch's discovery, a medical textbook still listed the following as causes for tuberculosis: "hereditary disposition, unfavorable climate, sedentary indoor life, defective ventilation, deficiency of light, and 'depressing emotions." ${ }^{\prime 68}$ After experimenting with the newly discovered staphylococci and streptococci bacteria, Koch and his pair of laboratory assistants redirected their efforts onto tuberculosis using innovative techniques. On March 24, 1882, Koch first revealed to the Berlin Physiological Society "with great clarity and in unrefutable [sic] terms that the tubercle bacillus, Mycobacterium tuberculosis, [was] the cause of tuberculosis." The announcement was reported to have silenced the 200-person audience "stunned by the unassailability of Koch's work." ${ }^{69}$ News of Koch's presentation and accompanying paper, published on April 10 and entitled "The Etiology of Tuberculosis," spread relatively swiftly, reaching the English-speaking world in less than a month. While Koch's subsequent assertions that he had discovered the cure for tuberculosis were widely invalidated, his landmark pronouncement of the tubercle bacillus' existence was transformative for the medical community and, more gradually, the tragic nature of the consumptive myth.

In 1886, four years after Koch's discovery, an essay in The Nineteenth Century proclaimed that scientific breakthroughs were rendering previously sentimentalized illnesses artistically barren. In it, Nestor Tirard avows:

Every disease when first discovered has its picturesque aspect, but the progress of science gradually robs it of this, and destroys 
its artistic value. ... We all know too much about them; they are deprived all romance. ... [This] is true of consumption; once a favourite, it is now being neglected. The glittering eye, the hectic flush, the uncertainty of its lingering course, have been depicted again and again; but . . . all the symptoms are so well known at present that the subject is painful, if not actually of no value. ${ }^{70}$

Necessarily damaging to the foundations of the myth and its tragic potential, the designation of tuberculosis as contagious eradicated the disease's legendary, pathos-inducing exclusivity. No longer was consumption solely the "romantic disease," discerningly selecting its victims by virtue of their inherited social superiority, heightened delicacy, or extraordinary genius or passion. The "real" bacterial tuberculosis was indiscriminate and indifferent to the personal attributes of individual members of the populace, diminishing what Foucauldian discourse identifies as the essential nineteenth-century expression of individuality through illness. ${ }^{71}$ With anyone and everyone at risk for infection, consumption victims could no longer be interpreted as heroes falling from good fortune because of a tragic flaw. Sontag notes of the arbitrary nature of contagious diseases: "no one asks 'Why me?' who gets cholera or typhus." 72 The stigma historically attached to such diseases was now applicable to tuberculosis, demystifying and sullying its elite reputation.

The dismantlement of consumption's mythologized exclusivity provides The Doctor's Dilemma (1906) with much of its satirical bite. Ironically subtitled "A Tragedy," Shaw's play is a witty polemic of the British medical profession and the physician's unchecked authority to determine subjectively his patient's worth. In it, the exemplary tragic consumptive is pitted against the unremarkable victim of contagion in a battle for a cure. The lead physician on a promising medical trial, Dr. Ridgeon, must decide whether to administer an experimental tuberculosis treatment to Louis Dubedat, an exceptional artist whose creative genius fails to obscure a morally corrupt and profligate lifestyle, or Dr. Blenkinsop, a poor family physician of excellent character but mediocre talents. As Dr. Ridgeon articulates to a medical colleague, 'It's not an easy case to judge, is it? Blenkinsop's an honest decent man; but is he any use? Dubedat's a rotten blackguard; but he's a genuine source of pretty and pleasant and good things." In Shaw's sardonic inversion of the consumptive myth, the very same quality that purportedly left Dubedat vulnerable to tuberculosis (his artistic brilliance) also renders him more worthy of saving from the disease. Dubedat's thinly veiled fascination with and deployment of the preKoch consumptive myth is bested only by his doting wife Jennifer's unconscious espousal of it. Upon learning of Ridgeon's choice to cure Blenkinsop instead of her husband, Jennifer challenges the physician's decision with questions inspired by her credence in Dubedat's tragic heroism: "Can you not forgive him for being 
superior to you? for being cleverer? for being braver? for being a great artist?"'73

Marginalized by the nineteenth-century consumptive myth as undesirable recipients of the romantic disease, the poor were increasingly recognized as victims of tuberculosis at the turn of the century. Thomas Dormandy notes: "Tuberculosis picked out and killed a few Princes and it carried off more than one bejeweled, tender-hearted courtesan; but it slaughtered the poor by the million." Statistics showed that the impoverished were five times more likely to contract the disease, and the infant death rates from phthisis were considerably higher in enclaves of poverty than in neighborhoods inhabited by the financially solvent. ${ }^{74}$ According to Nan Marie McMurry, "[i]n the early nineteenth century consumption shared a beneficent constellation with ideas of individuality, beauty, intelligence, and spirituality. . . [I]n the late nineteenth century [these] were challenged and overshadowed by a new pejorative stereotype. The tuberculosis victim at the turn of the century was a creature of ignorance, poverty, and immorality, who seemed to deserve illness." 75 This profound shift is registered in Sean O'Casey's The Plough and the Stars (1926), which features a lower-class teenaged consumptive named Mollser who resides with her mother in a crowded Dublin tenement. Though her father was also tubercular, Mollser's genetic link to the disease is deemphasized by her cramped living conditions and inadequate diet. A sympathetic but nevertheless inferior character, Mollser possesses none of the glorified beauty of the venerated female consumptive; instead, she is "shrivelled [sic]" up by "the ravages of consumption. ... [S] [Se is pitifully worn, walks feebly, and frequently coughs." ${ }^{\prime 76}$ Urban overcrowding, malnutrition, and inadequate hygiene became the targets of the crusade to eradicate tuberculosis: "the identification of the sick, the razing of slums, and the efforts at inculcating habits of personal hygiene amounted to a vast campaign for the control and moralization of the lower classes." 77 The disease grew only baser in its connections with urban decay, the impoverished class, and the body fluid that was now thought to carry the bacilli most capably, sputum. City ordinances in Europe and North America were instituted prohibiting spitting in public places for fear that "dry phthisical sputa sticking to the floor, clothing, etc., [which remains] virulent for a long time, if inhaled as dust into the lung" could cause tuberculosis. ${ }^{78}$ Perhaps clinging to the tattered vestiges of the disease's social exclusivity, Dr. James T. Whittaker, in an 1882 lecture delivered at the College of Physicians of Philadelphia, appeals to bourgeois notions of gentlemanly decorum in warning against spitting: "with our knowledge of the danger which lurks in the sputum often, how much graver insult it is than a mere breach of propriety, how much deeper offence than a mere disgrace." 79

As O'Casey's drama ably illustrates, tuberculosis's conversion into an infectious disease also relocated the enemy from inside the tragic consumptive body to outer environs, where the microscopic tubercle bacillus patiently waited in streets, in buildings, on clothing, on rugs, etc. The disease was now capable 
of far worse than consuming its chosen victim from the inside and "burning up" upon the completion of its task; it was airborne and unpredictable in its pattern of dormancy and activation. As Jennifer Dubedat remarks to Ridgeon in The Doctor's Dilemma, she and her tubercular husband are "[treated] like lepers at the hotels." ${ }^{80}$ Now contagious and exteriorly oriented (as opposed to inherited and interior), the post-Koch construction of tuberculosis easily adheres to Peter Brooks's aforementioned characterization of the evil force in melodrama: "down this road, into this space [of innocence], a villain ... will come to insinuate himself." ${ }^{\text {81 }}$ This shift transforms tuberculosis from a bearer of tragedy to what Heilman categorizes as a disaster. "In disaster, what happens comes from without; in tragedy, from within. In disaster, we are victims; in tragedy, we make victims, of ourselves or others. In disaster, our moral quality is secondary; in tragedy, it is primary, the very source is action. ${ }^{\prime \prime 2}$ Echoing Brooks's assertions, Heilman's literatures of disaster, the voluminous written works dedicated to non-tragic catastrophes, are part of a larger good-versus-evil genre, that of melodrama. Robbed of its tragic trappings and aesthetic romanticism, modern tuberculosis joined syphilis, smallpox, and typhus as (evil) scourges of (good) humanity.

The individual sufferer/society dynamic unavoidably transformed in response to Koch's new evidence. Because the cure for tuberculosis was nearly 60 years away, isolation proved to be the only sound method for combating what Pamela K. Gilbert labels "the nineteenth century's twin terrors - the disintegration of the physical and social body." ${ }^{93}$ France's fin-de-siècle mandatory declaration policy, in which doctors were obligated to officially register cases of tuberculosis with authorities, "subordinated [individual rights] to the right of others to be free from contagion." " The soothing familial bedchamber gave way to the isolated sickroom, and a new category of sanatorium joined the luxurious rest home of the wealthy consumptive: the sanitized and impersonal contagious disease hospice reserved for late stage consumptives. In Eugene O'Neill's Long Day's Journey Into Night (1940), Edmund Tyrone's diagnosis of tuberculosis instigates a family feud over the proper course of therapy. His father James urges Edmund to seek treatment at a cheaper, state-run asylum (and in doing so reopens old wounds inflicted by James's miserly disposition and questionable priorities), while Jamie desires his brother's admittance into a private sanatorium. Like Shaw, O'Neill commingles vestiges of the disintegrating consumptive myth (Edmund is the archetypal consumptive poet, feverish and femininized, while James clings to antiquated notions of consumption's genetic triggers) with new understandings of the disease's pathology, infectiousness, and fatality rates, as articulated by Jamie. As the exclusive individuality of the consumptive victims and the mythologized displacing of their suffering onto caregivers waned at the twentieth century's dawning, so too did the promise of a gentle demise. Antithetical accounts of tubercular deaths had always been present, but the mild suffering enacted by the tragic heroes of consumption seemed to be 
too singular for the infected masses. Unlike the painless passing of Little Eva, Mollser's mother describes her daughter's suffering immediately before her death as "terrible bad." Louis Dubedat's deliberate and consummate reenactment of the mythic tragic demise à la Marguerite Gautier, for which he amasses an unsuspecting group of spectators to witness his final breath, is rejected by Ridgeon as artificial, romanticized, and vainglorious. ${ }^{85}$ Interestingly, critics at the 1906 London premiere of The Doctor's Dilemma responded contradictorily to Dubedat's death scene. The Tribune's reviewer seemed to grasp Shaw's irreverence, labeling the death scene "enormously clever in an uncanny fashion," while the Daily Telegraph's reviewer, apparently still rooted in the pre-Koch myth, called it "a very harrowing death scene ... pathetic and almost tragic. ${ }^{" 86}$

The tragic construction of consumption proved to be surprisingly resilient against the sobering flood of myth-busting statistics, and only truly subsided in the mid-twentieth century with the introduction of streptomycin. ${ }^{87}$ "The reason for this," posits Lawlor, "was that different narratives of consumption were still performing certain important discursive functions in society." ${ }^{\prime 88}$ This is especially true in the continued admiration of the nearly skeletal, translucent-skinned female form originating in the romanticized consumptive body. However, the consumptive myth was not the fixed and unrelenting force submitted by Sontag, nor did Koch's 1882 discovery of the tubercle bacillus render the tragic myth instantaneously obsolete. The consumptive myth and modern notions of tuberculosis should instead be seen as occupying opposing ends of a dialectical seesaw; the consumptive myth loses its cultural currency and tragic potential as the transmittable and indiscriminate tuberculosis rises in influence.

\section{Notes}

1. Marguerite in Alexandre Dumas fils, Camille (La dame aux camélias), trans. Edith Reynolds and Nigel Playfair, Camille and Other Plays, ed. Stephen S. Stanton (New York: Hill and Wang, 1957) 105-64.

2. Harriet Beecher Stowe, Uncle Tom's Cabin or, Life Among the Lowly, ed. Ann Douglas (Harmondsworth: Penguin, 1981) 401.

3. Hugo Engel, "The Etiology of Tuberculosis," Philadelphia Medical Times (1871-1889), 9 September 1882. 12, 25.

4. David S. Barnes, The Making of a Social Disease: Tuberculosis in Nineteenth-Century France (Berkeley: U of California P, 1995); John Conway, Loomis: The Man, The Sanitarium, and the Search for the Cure (Fleischmanns, NY: Purple Mountain P, 2006); Thomas M. Daniel, Captain of Death: The Story of Tuberculosis (Rochester: U of Rochester P, 1997); Thomas M. Daniel, Joseph H. Bates, and Katharine A. Downes, "History of Tuberculosis," Tuberculosis: Pathogenesis, Protection, and Control, ed. Barry R. Bloom (Washington DC, American Society for Microbiology, 1994); Thomas Dormandy, The White Death: A History of Tuberculosis (New York: New York U P, 2000); Georgina D. Feldberg, Disease and Class: Tuberculosis and the Shaping of Modern North American Society (New Brunswick, NJ: Rutgers U P, 1995); Diane Price Herndl, Invalid Women: Figuring Feminine Illness in American Fiction and Culture, 1840-1940 (Chapel Hill: U of North Carolina P, 1993); Nicholas John, ed., Violetta and Her Sisters: The Lady of the Camellias: Responses to the Myth (London: Faber and Faber, 1994); R.Y. Keers, Pulmonary Tuberculosis: A Journey Down the Centuries (London: Baillière Tindall, 
1978); Clark Lawlor, Consumption and Literature: The Making of the Romantic Disease (Basingstoke: Palgrave MacMillan, 2006); Clark Lawlor and Akihito Suzuki, "The Disease of the Self: Representing Consumption, 1700-1830," Bulletin of Historical Medicine 74 (2005): 287-307; Nan Marie McMurry, “"And I? I am in a Consumption:' The Tuberculosis Patient, 1780-1930," diss., Duke U, 1985); B. Meyer, "Till Death Do Us Part: The Consumptive Victorian Heroine in Popular Romantic Fiction," Journal of Popular Culture 37.2 (2003): 287-308; Lewis J. Moorman, Tuberculosis and Genius (Chicago: U of Chicago P, 1940); Charlotte A. Roberts and Jane E. Buikstra, "The History of Tuberculosis From Earliest Times to the Development of Drugs," Clinical Tuberculosis, 3rd ed., ed. Peter D. O. Davies (London: Arnold, 2003); Barbara Gutmann Rosenkrantz, ed., From Consumption to Tuberculosis: A Documentary History (New York: Garland Publishing, 1994); F. B. Smith, The Retreat of Tuberculosis, 1850-1950 (London: Croom Helm, 1988); Susan Sontag, Illness as Metaphor (New York: Farrar, Straus and Giroux, 1977); Michael E. Teller, The Tuberculosis Movement: A Public Health Campaign in the Progressive Era (New York: Greenwood P, 1988); and Athena Vrettos, Somatic Fictions: Imagining Illness in Victorian Culture (Stanford, CA: Stanford U P, 1995).

5. I will be using Clark Lawlor's useful term "consumptive myth" throughout this essay.

6. Daniel 30.

7. Raymond Williams, Modern Tragedy, ed. Pamela McCallum (Ontario: Broadview Encore Editions, 2006) 69.

8. Williams 79. The italics are mine.

9. Terry Eagleton, Sweet Violence: The Ideal of the Tragic (Malden, MA: Blackwell Pub., 2003); Northrop Frye, "The Mythos of Autumn: Tragedy," Tragedy, Vision, and Form, ed. Robert W. Corrigan (San Francisco: Chandler Publishing, 1965) 124-135; Robert B. Heilman, "Tragedy and Melodrama: Speculations on Generic Form," Tragedy, Vision, and Form, 205-215; Kenneth A. Telford, Aristotle's Poetics: Translation and Analysis (Chicago: Henry Regnery, 1970). See also Miriam Bailin, The Sickroom in Victorian Fiction: The Art of Being Ill (Cambridge: Cambridge U P, 1994); Allan Conrad Christensen, Nineteenth-Century Narratives of Contagion: 'Our feverish contact'(London: Routledge, 2005); Pamela K. Gilbert, Disease, Desire, and the Body in Victorian Women's Popular Novels (Cambridge: Cambridge U P, 1997); Claudine Herzlich and Janine Pierret, Illness and Self in Society, trans. Elborg Forster (Baltimore: Johns Hopkins U P, 1987); Linda Hutcheon and Michael Hutcheon, Opera: Desire, Disease, Death (Lincoln: U of Nebraska P, 1996); Deborah Epstein Nord, Walking the Victorian Streets: Women, Representation, and the City (Ithaca: Cornell U P, 1995); Laura Otis, Membranes: Metaphors of Invasion in Nineteenth-Century Literature, Science, and Politics (Baltimore: Johns Hopkins U P, 1999); Nancy Tomes, "Epidemic Entertainments: Disease and Popular Culture in Early Twentieth-Century America," American Literary History (2002) 625-52; and Martin Wallen, City of Health, Fields of Disease: Revolutions in the Poetry, Medicine, and Philosophy of Romanticism (Aldershot: Ashgate Publishing, 2004).

10. George Aiken, Uncle Tom's Cabin, The Longman Anthology of Drama and Theater, eds. Michael L. Greenwald, et. al. (New York: Pearson Longman, 2001) 798-827; Sean O'Casey, The Plough and the Stars, in Collected Plays: Volume One (London: Macmillan and Co, 1950) 160-261; Eugene O’Neill, Long Day's Journey Into Night (New Haven: Yale U P, 1955); George Bernard Shaw, The Doctor's Dilemma (London: Penguin Books, 1906); and Tom Taylor, Helping Hands (London: T.H. Lacy, c.1880).

11. Dormandy 22. The familiar sign of TB have been found in preserved Egyptian mummies, with the spine of one young female still holding the microscopic tubercle bacilli that precipitated her untimely end. The word phthisis was coined in ancient Greek; it translates as "wasting." Most histories of the disease identify tuberculosis as a prehistoric cause of death. According to Susan Sontag's Illness as Metaphor, "The Oxford English Dictionary records 'consumption' in use as a synonym for pulmonary tuberculosis as early as 1398 " (9). In order to distinguish between the pre-1882 mythologized tuberculosis and its post-1882 reconstruction phase, I will refer to the former as "consumption" and the latter as "tuberculosis". It is important to note, however, that both terms were used on either side of Koch's discovery.

12. Daniels 30.

13. Smith 26-7.

14. Dormandy 22.

15. Clark Lawlor graphically enumerates the corporeal markers of acute tuberculosis in 
Consumption and Literature: The Making of the Romantic Disease:

As the disease progresses, the patient becomes emaciated and even skeletal, with the lips drawn back to reveal teeth; eye sockets are hollowed and bones stick out from the flesh. The 'hectic fever' worsens, characteristically strongest towards the evening, giving the patient's skin a vivid 'hectic flush' which strongly contrasts the otherwise whitened and drained appearance. Blue veins are often apparent under the seemingly transparent skin. Coughing too increases as the lungs disintegrate: the patient may expectorate blood and other matter, often with a fetid smell (5).

16. Smith 2.

17. Lawlor 5.

18. Edgar Allan Poe, "Metzengerstein," The Saturday Courier (Philadelphia), 14 Jan 1832, 12 July $2008<$ http://www.eapoe.org/WORKS/tales/metzngna.htm> 1 .

19. By placing quotation marks around "true" identity, I am intentionally complicating the essentialist idea that a metaphor-free tuberculosis is or has ever been possible. As David Barnes has asserted, the desire expressed by Sontag and others to rescue the victims of illness from the devaluing waters of historical and cultural narrative cannot hope to succeed.

20. Aristotle 23.

21. Eagleton 86,87 .

22. Prior to Koch's discovery of the tubercle bacillus, the dominating consumptive myth culturally silenced all medical theories proposing the contagious nature of tuberculosis.

23. For accounts of the Brontës' ongoing battle with consumption see Beth Torgerson, Reading the Brontë Body: Disease, Desire, and the Constraints of Culture (New York: Palgrave MacMillan, 2005) 129-30; Rebecca Fraser, The Brontës: Charlotte Brontë and Her Family (New York: Crown Publishers, 1988), and Daniel 31-2.

24. Lawlor 44, 51. Treatments for consumptives expanded during the Enlightenment to reflect the medical community's developing appreciation for the disease and its stages: "In the initial 'inflammatory' phase, the stage of plethora, an 'antiphlogistic' regimen of blistering, vomiting, purging, bleeding and a light diet was indicated while in the second phase, that of 'ulceration,' balsams, expectorants, lime water and opium constituted the main therapy" (Keers 66).

25. Dormandy 91,92. To contemporary generations familiar with Heroin Chic, the haute couture phenomenon of the early 1990s, the appropriation of a physique developed through illness by the fashionable circles of society is not unfathomable.

26. Thomas Beddoes, Essay on the causes, early signs, and prevention of pulmonary consumption for the use of parents and preceptors (Bristol: Biggs and Cottle, 1799), 124. Beddoes, like many upper class physicians of his day, was unconcerned with the sustained health of those with mean incomes, directing his advice strictly to the upper echelons of society. See also 'Hygeia, 'or Essays Moral and Medical, [Vol.] 3 (Bristol: J. Mills, 1802) and Manual of Health: or, The Invalid Conducted Safely through the Seasons (London: J. Johnson, 1806).

27. According to Lawlor, Barry's treatise on consumption: "is careful to stress that people in the British Isles, 'particularly the better sort', are more liable to 'an Haemoptoe [a burst blood vessel], and thence a Phthisis, from their exorbitant use of Animal Diet high Sauces, and Spirituous liquors . . . ' Here, economic over-consumption is responsible for the medical variety . . .... Although the disease is not desirable here, it does serve as a rough index of a nation's and an individual's wealth. Britain is prosperous, therefore consumption is common: the middle and upper classes are the richest people in the nation, so they are more likely to be smitten with this disease of indulgence" (45-46).

28. Herzlich and Pierret 24.

29. Aiken $804,805,812$.

30. In Stowe's novel, Ellen is identified as having the last name of "Sanders", along with another woman named Maria (162). However, Eliza Jane has no surname in both the play and novel, leaving open the possibility of a familial connection.

31. Eagleton 8 .

32. Aiken 813.

33. Lawlor 116.

34. Herzlich and Pierret 25. 
35. Sontag 46. Though Illness as Metaphor inveighs against the historical chastisement of consumptives for their supposed agency in becoming ill, Sontag acknowledges that within the myth "TB always had pathos. Like the mental patient today, the tubercular was considered to be someone quintessentially vulnerable, and full of self-destructive whims" (63-64).

36. According to Nan Marie McMurry, authors of both medical and fictional writings depicted tuberculosis as the "fell destroyer" that "selected for its sacrifices" the "flowers of the flock," or "the fairest and loveliest" (x).

37. Lida Rose McCabe, "The Centenary of Camille: Paris Celebrates Marie Duplessis, the Original of La Dame aux Camélias," New York Times 13 January 1924, SM11. Italics mine.

38. Hutcheon and Hutcheon 44.

39. Sontag 63.

40. While contemporary writings on the sources of tuberculosis sometimes cite sexual deviancy, masturbation, or an excessive libido as potential causes, the occupation of Marguerite is not substantially emphasized in connection with her illness in many stage adaptations. In Sarah Bernhardt's First Theatrical Tour, Patricia Marks cites one Louisville reviewer of Dame Sarah's turn-of-the-century portrayal of Marguerite. The reviewers, "after a prefatory defense in staging 'delicate' subjects, submits that adultery is as 'legitimate' as other commonplace theatrical topics like murder and forgery, and concludes that, despite Marguerite's fall from virtue, 'the play is not at all immodest, and it most assurdedly [sic] is not immoral" (128). Rather, Marguerite's wild partying with the Parisian elite is blamed for her weak immune system, which in turn permits the disease to progress rapidly. Patricia Marks, Sarah Bernhardt's First American Theatrical Tour (North Carolina: McFarland and Co., 2003); George C. D. O'Dell's multivolume Annals of the New York Stage for accounts of Camille productions throughout the nineteenth century (New York: Columbia U P, 1931); and Katie N. Johnson's Sisters in Sin: Brothel Drama in America, 1900-1920 (Cambridge: Cambridge U P, 2006).

41. Qtd. in Dormandy 70.

42. Dumas fils 141 .

43. Taylor 6.

44. Taylor 9.

45. Peter Brooks, The Melodramatic Imagination: Balzac, Henry James, Melodrama, and the Mode of Excess (New Haven: Yale U P, 1995) 29.

46. Heilman 246, 247.

47. Williams 80-1.

48. Herzlich and Pierret xi, 25.

49. Qtd. by Fraser 319. Nearly twenty years before Koch's pronouncement, physician Henry I. Bowditch warned of tuberculosis's contagious nature (though he did not have Koch's bacteriological proof). Bowditch's 1864 treatise "Is Consumption Ever Contagious, or Communicated by One Person to Another in Any Manner?" ends with stern advice to the loved ones of consumptives: "we should warn a wife or a sister or near female friend from devoting herself too closely to the attendance upon a consumptive husband, sister or friend. For the sake of the attendant as well as the sick one, sleeping in the same bed, or even in the same room, should be avoided" (in Rosenkrantz 43-56, 54).

50. Aiken 814 .

51. Taylor 30.

52. Aristotle 20.

53. Meyer 290. The reputed phenomenon of spes phthisica proved one of the longest lasting components of the consumptive myth. In his rather old-fashioned tribute to tubercular geniuses both real and fictional (written in 1940, but a few years before the introduction of streptomycin), Lewis J. Moorman dramatically avows "how optimistic [consumptives] may be even when life is literally being cut down by the inevitable sweep of the Great Reaper" (x).

54. Dormandy 71.

55. Meyer 290.

56. Sontag 30.

57. Aiken 814.

58. Dumas 162.

59. Dumas 162, 163.

60. Frye 128. In yet another link between tragedy and the consumptive myth, autumn imagery 
was regularly associated with the slow consumptive death. See Lawlor 169-70.

61. Don Wilmeth, ed., The Cambridge Guide to American Theatre, 2nd hardcover ed. (Cambridge: Cambridge U P, 2007) 658. For production history of Uncle Tom's Cabin see Harry Birdoff, The World's Greatest Hit: Uncle Tom's Cabin (New York: S.F. Vanni, 1947) and Thomas F. Gossett, Uncle Tom 's Cabin and American Culture (Dallas: Southern Methodist U P, 1985).

62. Unknown newspaper clipping New York Tribune 3 June 1905. Harvard Theatre Collection; Barbara Wallace Grossman, A Spectacle of Suffering: Clara Morris on the American Stage (Carbondale: Southern Illinois U P, 2009) 198.

63. Unknown newspaper clipping, New York Evening Sun, 23 March 1898, Harvard Theatre Collection.

64. Eagleton 169.

65. Eagleton 169.

66. Otis 25 .

67. Until the late nineteenth century, most infectious diseases were not believed to be contagious (plague and syphilis being notable exceptions). For more on Laënnec see Dormandy 27-40.

68. Qtd. by Sontag 54.

69. Daniels 80-1.

70. Nestor Tirard, "Disease in Fiction," The Nineteenth Century 20.116 (October 1886) 579-91, 581.

71. See Otis and Martin Wallen's City of Health, Fields of Disease: Revolutions in the Poetry, Medicine, and Philosophy of Romanticism (Aldershot: Ashgate Publishing Ltd, 2004).

72. Sontag 38 .

73. Shaw $135,160$.

74. Dormandy $73,77$.

75. McMurry viii.

76. O'Casey 190.

77. Herzlich and Pierret 26.

78. Engel 843.

79. James T. Whittaker, "Original Lectures: The Bacillus Tuberculosis," Medical News 30 September 1882: 365.

80. Shaw 122.

81. Brooks 29.

82. Heilman 251.

83. Gilbert 18. Until streptomycin was approved for distribution in 1944, the treatment of tuberculosis patients remained relatively unchanged after the discovery of the tubercle bacillus.

84. Barnes 104.

85. O'Casey 238.

86. Quoted by Desmond MacCarthy, London Sunday Times, unknown newspaper clipping, c. 1906, Harvard Theatre Collection.

87. The tragic consumptive myth has been transformed into parody courtesy of Ridiculous Theatre founder Charles Ludlum, who adapted and updated La dame aux camélias in 1973. Ludlam, who once declared, "I think that I am the Camille of our era," played the doomed courtesan without the quintessential campiness that normally accompanied a drag performance. An avid fan of Greta Garbo's portrayal of Marguerite in George Cukor's 1938 film, Ludlum wore a period gown and a wig of sablehued ringlets, but deliberately allowed his coarse chest hair to peek out of the costume's bodice. While Ludlam prided himself on outrageous theatrical works that challenged tradition and identity politics, he did aspire to honor Dumas's play and its mythic heroine. "When the audience laughed at my pain, the play seemed more tragic to me than when they took it seriously. A solemn audience trivialized the event. This [irony] of Camille was the ultimate masochism. I went out there to try to have a happy ending every night and got knocked down by every peripeteia of the plot. How could I continue such a pessimistic enterprise?" (Kaufman 193). For descriptions of Ludlum's Camille, see David Kaufman's Ridiculous! The Theatrical Life and Times of Charles Ludlam (New York: Applause, 2003) and Rick Roemer's Charles Ludlam and the Ridiculous Theatrical Company (Jefferson: McFarland, 1998). Contemporary reviews of the performance were printed in the Los Angeles Times, New York Times, and Washington Post.

88. Lawlor 187. 